Article

\title{
Protective Effects of Dihydromyricetin against -OH-Induced Mesenchymal Stem Cells Damage and Mechanistic Chemistry
}

\author{
Xican Li ${ }^{1, *}$, Jingjing Liu ${ }^{1}$, Jian Lin ${ }^{2}$, Tingting Wang ${ }^{1}$, Jieyuan Huang ${ }^{1}$, Yongqiang Lin ${ }^{1}$ \\ and Dongfeng Chen ${ }^{2, *}$ \\ 1 School of Chinese Herbal Medicine, Guangzhou University of Chinese Medicine, Guangzhou 510006, China; \\ 15622829151@163.com (J.L.); wtttx0304@163.com (T.W.); jieyuan_huang@163.com (J.H.); \\ yorkoran@foxmail.com (Y.L.) \\ 2 School of Basic Medical Science, Guangzhou University of Chinese Medicine, Guangzhou 510006, China; \\ linjianchn@outlook.com \\ * Correspondence: lixican@126.com (X.L.); cdf27212@21cn.com (D.C.); Tel.: +86-203-935-8076 (X.L.) \\ Academic Editor: Isabel C. F. R. Ferreira \\ Received: 23 February 2016; Accepted: 28 April 2016; Published: 9 May 2016
}

\begin{abstract}
As a natural flavonoid in Ampelopsis grossedentata, dihydromyricetin (DHM, $2 R, 3 R-3,5,7,3^{\prime}, 4^{\prime}, 5^{\prime}$-hexahydroxy-2,3-dihydroflavonol) was observed to increase the viability of -OH-treated mesenchymal stem cells using a MTT [3-(4,5-dimethylthiazol-2-yl)-2,5-diphenyl] assay and flow cytometry analysis. This protective effect indicates DHM may be a beneficial agent for cell transplantation therapy. Mechanistic chemistry studies indicated that compared with myricetin, DHM was less effective at $\mathrm{ABTS}^{+} \bullet\left(2,2^{\prime}\right.$-azino-bis(3-ethylbenzothiazoline-6-sulfonic acid radical) scavenging and reducing $\mathrm{Cu}^{2+}$, and had higher $\bullet \mathrm{O}_{2}^{-}$and DPPH•(1,1-diphenyl-2-picrylhydrazyl radical) scavenging activities. Additionally, DHM could also chelate $\mathrm{Fe}^{2+}$ to give an absorption maximum at $589 \mathrm{~nm}$. Hence, such protective effect of DHM may arise from its antioxidant activities which are thought to occur via direct radical-scavenging and $\mathrm{Fe}^{2+}$-chelation. Direct radical-scavenging involves an electron transfer (ET) pathway. The hydrogenation of the 2,3-double bond is hypothesized to reduce the ET process by blocking the formation of a larger $\pi-\pi$ conjugative system. The glycosidation of the $3-\mathrm{OH}$ in myricitrin is assumed to sterically hinder atom transfer in the $\bullet \mathrm{O}_{2}{ }^{-}$and DPPH• radical-scavenging processes. In $\mathrm{DHM}$, the $\mathrm{Fe}^{2+}$-chelating effect can actually be attributed to the $5,3^{\prime}, 4^{\prime}, 5^{\prime}-\mathrm{OH}$ and $4-\mathrm{C}=\mathrm{O}$ groups, and the $3-\mathrm{OH}$ group itself can neither scavenge radicals nor chelate metal.
\end{abstract}

Keywords: dihydromyricetin; mesenchymal stem cells; antioxidant mechanisms; hydroxyl radical-induced; $\mathrm{Fe}^{2+}$-chelation; 3-OH group; 2,3-double bond; electron transfer (ET) pathway

\section{Introduction}

It is well documented that bone marrow-derived mesenchymal stem cell (bmMSC) transplantation represents one of the more promising new strategies in the treatment of various diseases such as neuronal regeneration [1,2], brain damage [3,4], liver damage [5], and heart failure [6]. In the process of transplantation, various reactive oxygen species (ROS) may cause oxidative damage and apoptosis [7]. These ROS mainly include superoxide radical anion $\left(\bullet \mathrm{O}_{2}^{-}\right)$, peroxynitrite $\left(\mathrm{ONOO}^{-}\right)$, hydroxyl radical $(\bullet \mathrm{OH})$, and so on.

The $\bullet \mathrm{O}_{2}^{-}$and $\mathrm{ONOO}^{-}$radicals however have recently been reported to be inhibited by the antioxidant defense system in bmMSCs to some extent [2,4]. Thus, bmMSCs themselves had antioxidant potential to decrease oxidative damage and apoptotic death [5]. However, such endogenous antioxidant potential cannot guarantee the cell survival for their clinical applications 
in cell transplantation and tissue engineering. Other more toxic ROS, especially hydroxyl radical $(\bullet \mathrm{OH})$, can severely damage the cells and result in poor cell survival following transplantation. The resistance to $\bullet \mathrm{OH}$-induced cellular damage or apoptosis may mainly rely on some exogenous effective antioxidants, such as natural flavonoids.

As a main flavonoid, dihydromyricetin (DHM, Figure 1A) occurs in Ampelopsis grossedentata (Hand-Mazz.) [8], and has attracted increasing attention owing to its beneficial effect on cells. It has been recently reported that DHM can protect endothelial cells from $\mathrm{H}_{2} \mathrm{O}_{2}$-induced oxidative damage via mitochondrial pathways [9], and exert antioxidant action in soybean oil and cooked ground beef model systems [10]. Additionally, the parent plant A. grossedentata has been consumed as a tea (Rattan Tea, Vine Tea, Tengcha) with health benefits in South China [11,12]. It is documented to be able to clear heat and remove toxic in the body according to Tradition Chinese Medicine (TCM) [11]. The so-called heat and toxic properties in TCM have been demonstrated by free radical biology to result from oxidative stress induced by ROS, especially the $\bullet \mathrm{OH}$ radical [13]. Taken together, these observations suggest that DHM may possess a beneficial effect on the apoptosis of MSCs, although to our knowledge, there is no direct evidence to support this. Therefore, we investigated the beneficial effects of DHM on the viability of $\bullet \mathrm{OH}$-treated MSCs using the MTT [3-(4,5-dimethylthiazol-2-yl)-2,5-diphenyl] assay and flow cytometry analysis.
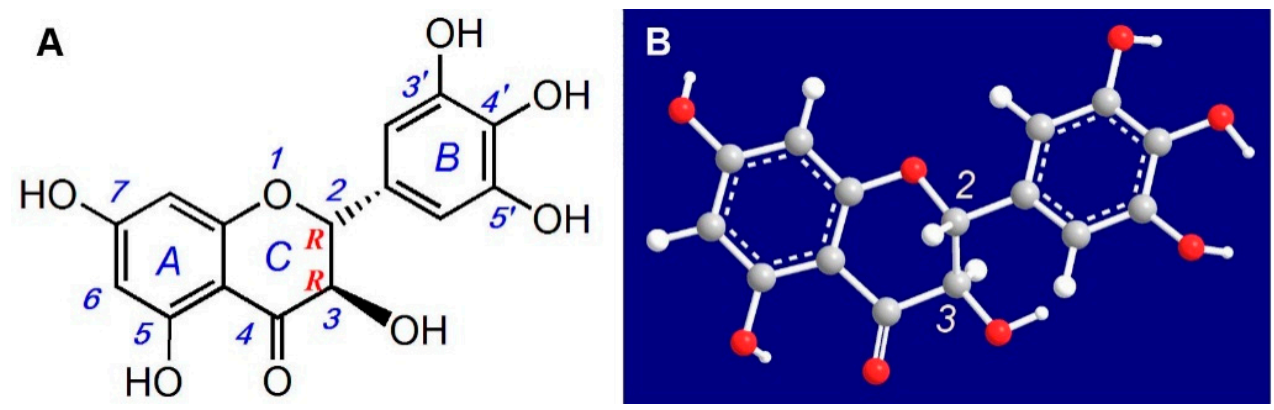

Figure 1. The chemical structure (A) and ball-stick model (B) of dihydromyricetin (DHM, $2 R, 3 R-3,5,7,3^{\prime}, 4^{\prime}, 5^{\prime}$-hexahydroxy-2,3-dihydroflavonol).

It must be emphasized that the structure of DHM has not been reported consistently in the literature. Zhu reported a structure with a double bond between the 2- and 3-positions of the DHM molecule [14]. Shen and colleagues incorrectly reported the stereo configuration of DHM [15]. Several other reports mentioned no stereo configuration for DHM [16-18]. These structural inconsistencies and errors may lead to misunderstandings about some of the chemical moieties in the DHM molecule. For example, the structure drawn by Zhu is actually myricetin, not dihydromyricetin (DHM) and the 3-OH was wrongly identified as a phenolic -OH group [14]. Zhang even stated that the 3-OH along with other $-\mathrm{OH}$ groups and $\mathrm{a}-\mathrm{C}=\mathrm{O}$ played a critical role in antioxidant action of DHM [8]. Therefore, the reliability of these results has been questioned.

Herein, we use a ball-stick model to intuitively show the stereo configuration of DHM. As illustrated in Figure 1B, the absolute configurations of C-2 and C-3 are $(R, R)$, and the full IUPAC name of DHM is $(2 R, 3 R)-3,5,7,3^{\prime}, 4^{\prime}, 5^{\prime}$-hexahydroxy-2,3-dihydroflavonol. Our detailed drawing should be helpful to understand the role of the 3-OH in DHM and other dihydroflavonoids. Furthermore, this work will support the screening of natural dihydroflavonoids and their synthetic derivatives as effective antioxidants for cell transplantation and tissue engineering purposes.

\section{Results and Discussion}

Chemical or physical environments such as radiation and iron overload can damage MSCs during the process of proliferation and differentiation because of the generation of the $\bullet \mathrm{OH}$ radical [19-21]. For example, radiotherapy for cancer patients has been indicated to decrease cell survival in autologous 
stem cell transplantation [22]; Iron overload can yield the $\bullet \mathrm{OH}$ radical through the Fenton reaction (Equation (1)) or Haber-Weiss (Equation (2)). In the present study, Fenton's reagent $\left(\mathrm{FeCl}_{2} \mathrm{plus} \mathrm{H}_{2} \mathrm{O}_{2}\right)$ was used to damage MSCs, and then the MTT assay was firstly used to evaluate the beneficial effect of $\mathrm{DHM}$ on $\bullet \mathrm{OH}$ radical-treated MSCs:

$$
\begin{gathered}
\mathrm{Fe}^{2+}+\mathrm{H}_{2} \mathrm{O}_{2} \rightarrow \mathrm{Fe}^{3+}+\mathrm{OH}^{-}+\bullet \mathrm{OH} \\
\bullet \mathrm{O}_{2}^{-}+\mathrm{H}_{2} \mathrm{O}_{2} \rightarrow \mathrm{OH}^{-}+\bullet \mathrm{OH}+\mathrm{O}_{2}
\end{gathered}
$$

As shown in Figure 2A, the viability of MSCs in the control group was $100 \%$. By comparison, the model group treated with Fenton's reagent exhibited the lowest cell viability (40.3\%) indicating that the MSCs in the model group were oxidatively damaged. However, the viabilities of MSCs in the sample groups (31.2-312.2 $\mu \mathrm{M}$ DHM) were effectively restored indicating an anti-apoptotic effect of DHM on MSCs. The anti-apoptotic effect was further investigated using flow cytometry. As shown in Figure 2B, MSC apoptosis was quantified by staining the cells with annexin-V-FITC/PI. The number of annexin $\mathrm{V}$-positive cells was $9.0 \% \pm 1.5 \%$ in $\mathrm{MSC}$ s treated without $\mathrm{FeCl}_{2}$ and $\mathrm{H}_{2} \mathrm{O}_{2}, 53 \% \pm 2.6 \%$ in MSCs treated with $\mathrm{FeCl}_{2}$ and $\mathrm{H}_{2} \mathrm{O}_{2}$, and $32 \% \pm 2.7 \%$ and $26 \% \pm 3.1 \%$ in $\mathrm{MSC}$ s treated with $\mathrm{H}_{2} \mathrm{O}_{2}$ and $\mathrm{FeCl}_{2}$ in the presence of the indicated concentrations of DHM. There was a significant difference among the groups, post hoc comparisons revealed that the apoptotic cell number of the MSCs treated with $\mathrm{H}_{2} \mathrm{O}_{2}$ and $\mathrm{FeCl}_{2}$ was increased and this increase could be inhibited by DHM $(p<0.05)$.
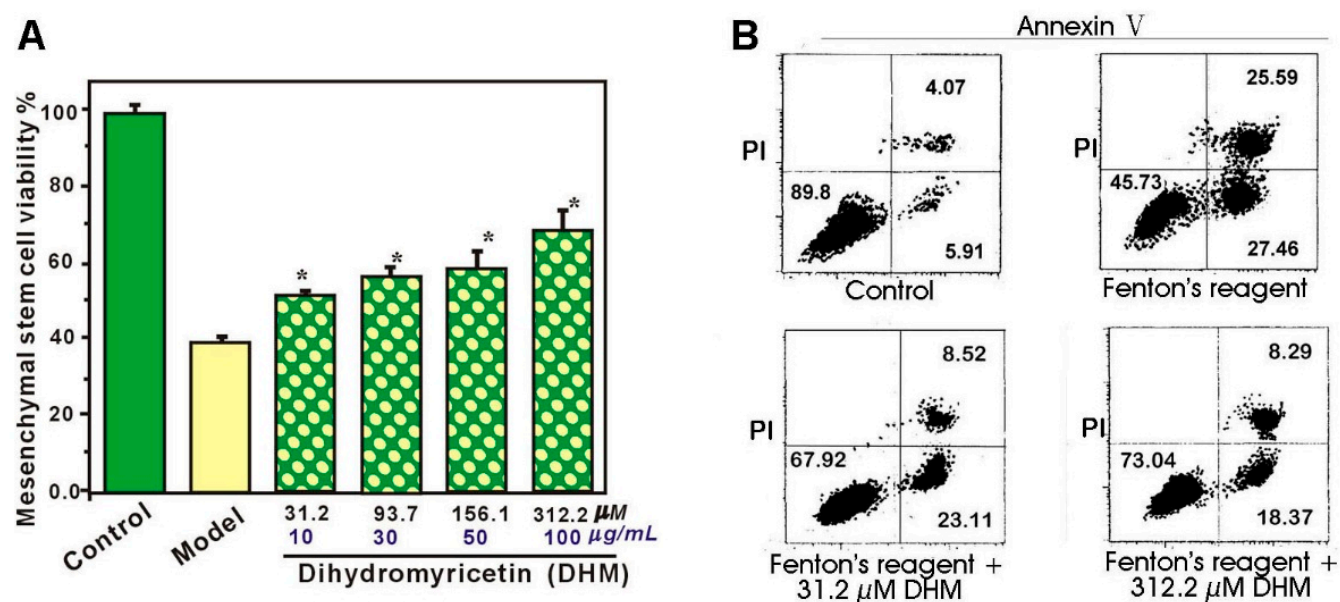

Figure 2. Dihydromyricetin (DHM) protects MSCs from Fenton's reagent-induced damage (or apoptosis): (A) MTT assay. Fenton's reagent refers to $\mathrm{FeCl}_{2}$ plus $\mathrm{H}_{2} \mathrm{O}_{2}$. Experiments were performed with three batches of cells and each batch was tested in triplicate. Data are the mean \pm SD. ${ }^{*} p<0.05$, compared with MSC damage following Fenton's reagent; (B) Flow cytometry analysis. Fenton's reagent refers to $\mathrm{FeCl}_{2}$ plus $\mathrm{H}_{2} \mathrm{O}_{2}$. MSCs were treated with or without Fenton's reagent in the absence or presence of DHM at the indicated concentrations. The apoptotic cells were analyzed by means of flow cytometry for annexin V and PI. This assay was performed to distinguish intact cells (annexin V-/PI-), necrotic (annexin V-/PI+) cells, early apoptotic (annexin V+/PI-) cells, and late apoptotic/necrotic (annexin $\mathrm{V}+/ \mathrm{PI}+$ ) cells. Experiments were performed with two batches of cells and each batch was tested in duplicate. Data are shown as the mean $\pm \operatorname{SD}(n=4) .{ }^{*} p<0.05$, compared with the Fenton's reagent treatment group.

These observations partly support why DHM protected PC12 cells from apoptosis induced by SNP, a reagent which can release massive amounts of the free radical NO [23]. This further supports the fact that Tengcha tea can prevent hypolipidemia in mice [12], and $\mathrm{FeSO}_{4}$-edetic acid-induced lipid peroxidation in the presence of linoleic acid [8]. More importantly, these results support the potential 
application of DHM in MSC transplantation therapy, especially when the cells have been subjected to radiation (especially in radiotherapy), iron overload, or other oxidative stress factors.

Additionally, such protection has been demonstrated to be partly attributed to the repair of DNA oxidative damage [24]. As shown in Figure 3, DHM exhibited a protective effect against DNA damage in a concentration-dependent manner in vitro. Its protective effect on DNA is reported to be directly associated with its fast repairing DNA radical and ROS scavenging (antioxidant) effect [25], and may be partly responsible for its anticancer effect because cancer and aging are closely related to $\bullet \mathrm{OH}$ radical-induced damage to cells and DNA [14,26,27].

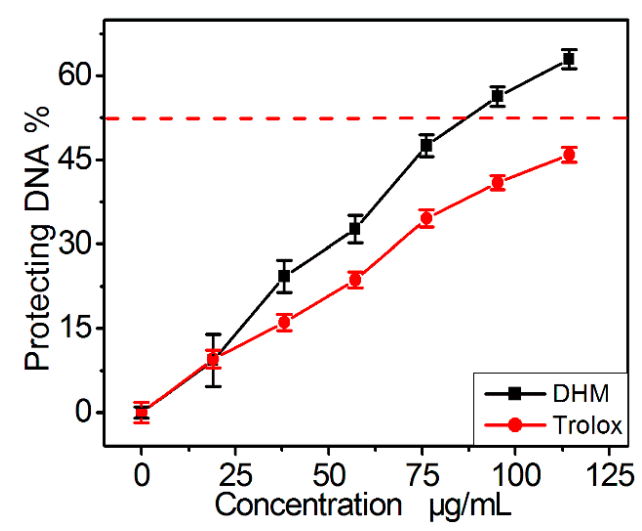

Figure 3. The protective effect of dihydromyricetin (DHM) against $\bullet \mathrm{OH}$-induced DNA damage in vitro. Each value is expressed as the mean $\pm \mathrm{SD}(n=3)$.

In the aspect of antioxidant effect, the value of the ratio of $\mathrm{IC}_{50 \text {,Trolox }} / \mathrm{IC}_{50, \mathrm{DHM}}$ (Table 1 ) revealed that DHM possessed 1.8-fold higher relative antioxidant effect the standard antioxidant Trolox. This is similar to its analogue myricitrin (Figure S1) which exhibited 1.7-fold higher antioxidant activity compared with Trolox (Table 1) [26]. Although myricitrin has a glucoside at C-3 and a double bond between the 2- and 3-positions, its antioxidant activities were similar to those of DHM. Thus, the antioxidant activities may result from the extreme reactivity of the $\bullet \mathrm{OH}$ radical, which can quickly and completely damage any nearby molecules or molecular moieties. Therefore, chemical moieties such as a double bond, sugar residues (glucosides), or $R / S$ configuration would not give distinguishing antioxidant results.

Table 1. The $\mathrm{IC}_{50}$ values of dihydromyricetin (DHM) and Trolox in various assays.

\begin{tabular}{|c|c|c|c|c|}
\hline \multirow{2}{*}{ Assays } & \multirow{2}{*}{$\begin{array}{c}\text { DHM } \\
\mu \mathrm{g} / \mathrm{mL}(\mu \mathrm{M})\end{array}$} & Positive Control & \multirow{2}{*}{$\mathrm{IC}_{50, \text { Trolox }} / \mathrm{IC}_{50, \mathrm{DHM}}$} & \multirow{2}{*}{$\begin{array}{c}\mathrm{IC}_{50, \text { Trolox }} / \\
\mathrm{IC}_{50, \text { myricitrin }}\end{array}$} \\
\hline & & Trolox, $\mu \mathrm{g} / \mathrm{mL}(\mu \mathrm{M})$ & & \\
\hline DNA assay & $85.7 \pm 2.2\left(266.7 \pm 0.5^{a}\right)$ & $120.6 \pm 0.7\left(483.3 \pm 0.5^{b}\right)$ & 1.8 & 1.7 \\
\hline $\begin{array}{c}\mathrm{ABTS}^{+} \\
\text {scavenging }\end{array}$ & $4.1 \pm 0.4\left(12.8 \pm 0.1^{b}\right)$ & $1.7 \pm 0.1\left(6.8 \pm 0.1^{\mathrm{a}}\right)$ & 0.5 & 1.8 \\
\hline $\mathrm{Cu}^{2+}$-reducing & $10.7 \pm 0.1\left(33.4 \pm 2.44^{\mathrm{a}}\right)$ & $10.3 \pm 0.1\left(41.2 \pm 0.9^{b}\right)$ & 1.3 & 3.0 \\
\hline$\cdot \mathrm{O}_{2}^{-}$scavenging & $6.7 \pm 0.2\left(20.0 \pm 0.4^{a}\right)$ & $23.2 \pm 2.6\left(90.1 \pm 0.5^{b}\right)$ & 4.5 & 1.9 \\
\hline $\begin{array}{l}\text { DPPH. } \\
\text { scavenging }\end{array}$ & $2.3 \pm 0.8\left(7.4 \pm 0.3^{\mathrm{a}}\right)$ & $8.78 \pm 0.2\left(35.1 \pm 0.4^{b}\right)$ & 4.7 & 1.2 \\
\hline $\mathrm{Fe}^{2+}$ chelating & $85.7 \pm 1.6\left(266.7 \pm 0.01^{b}\right)$ & $59.1 \pm 1.3\left(200.1 \pm 0.5^{\mathrm{a}}\right)^{* *}$ & 0.8 & No detected \\
\hline
\end{tabular}

Because catalytic iron (especially $\mathrm{Fe}^{2+}$ ) can accelerate the generation of $\bullet \mathrm{OH}$ radicals in the Fenton reaction or Haber-Weiss reaction (Equations (1) and (2)), $\mathrm{Fe}^{2+}$-chelation can decrease the level of $\bullet \mathrm{OH}$ radicals, and is regarded as indirect means of scavenging $\bullet \mathrm{OH}$ radicals [28]. 
To test the possibility that DHM may act as a direct radical scavenger, we used the ABTS $\bullet$ radical-scavenging assay where the $\mathrm{ABTS}^{+} \bullet$ radical can be generated without a metal catalyst. As shown in Figure 4A, DHM inhibited $\mathrm{ABTS}^{+} \bullet$ radical scavenging in a dose-dependent manner from 2 to $10 \mu \mathrm{g} / \mathrm{mL}$. However, the $\mathrm{IC}_{50}$ ratio (0.5 vs 1.8 ) showed that its ability was weaker than that of myricitrin. This may be linked to differences in the mechanism of $\mathrm{ABTS}^{+} \bullet$ scavenging between the two compounds.
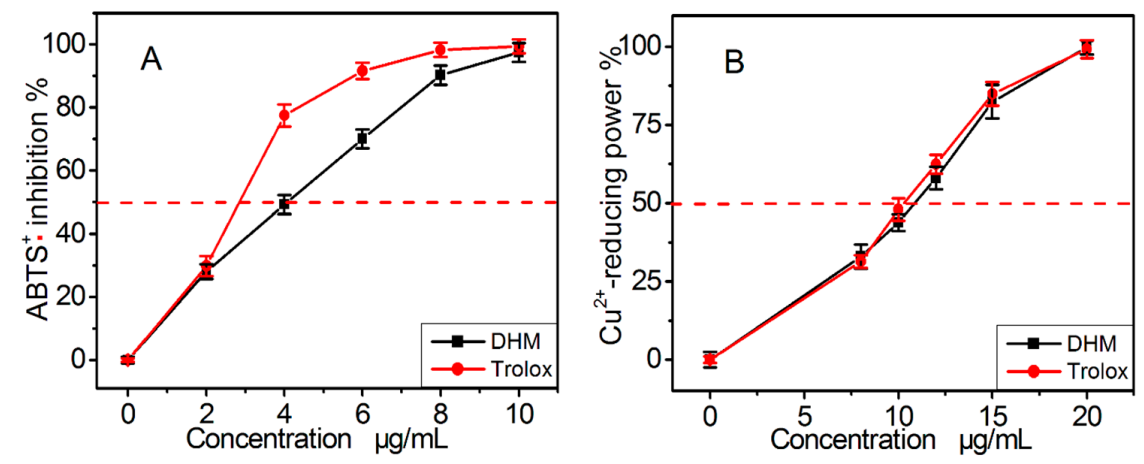

Figure 4. The dose response curves of dihydromyricetin (DHM) and positive control Trolox in the $\mathrm{ABTS}_{\bullet}{ }^{+}$radical-scavenging assay $(\mathbf{A})$ and $\mathrm{Cu}^{2+}$-reducing power assay $(\mathbf{B})$. Each value is expressed as the mean \pm SD $(n=3)$. Trolox, [( \pm )-6-hydroxyl-2,5,7,8-tetramethlychroman-2-carboxylic acid].

$\mathrm{ABTS}^{+} \bullet$ radical cation scavenging is considered to be an electron transfer (ET) process [29], similar to its formation, which was previously proven to be via one-electron oxidation from ABTS [30] (Figure 5). Based on this knowledge and the $\mathrm{ABTS}^{+} \bullet$ reaction with the pyrogallol moiety [31,32], we proposed the initial stage of the DHM reaction with the $\mathrm{ABTS}^{+} \bullet$ radical cation to occur as shown in Figure 6.

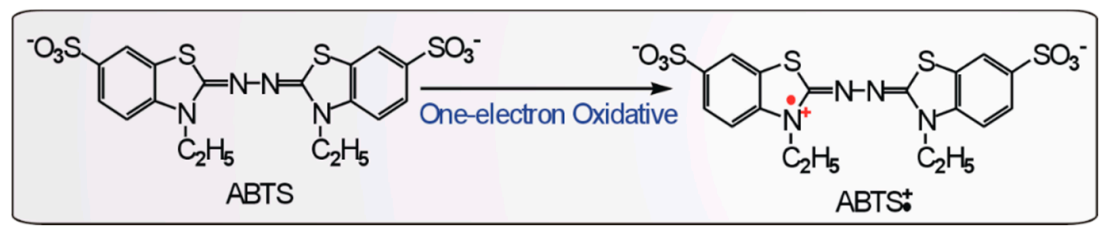

Figure 5. The one-electron transfer from ABTS to $\mathrm{ABTS}^{+} \bullet[30]$.

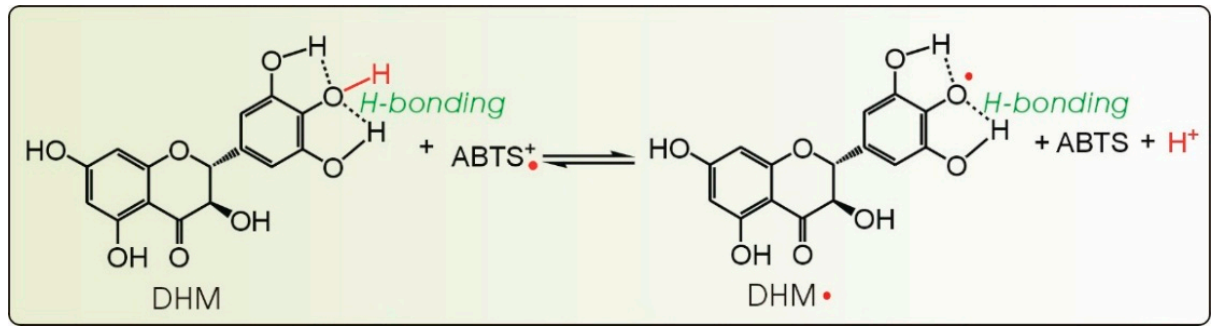

Figure 6. The proposed reaction of DHM with the $\mathrm{ABTS}^{+} \bullet$ radical cation (initial stage).

To further test the possibility of an ET process occurring during radical scavenging, DHM was investigated using a $\mathrm{Cu}^{2+}$-reducing assay. The metal reducing reaction is known as an ET process, and the $\mathrm{Cu}^{2+}$-reducing assay is normally utilized to explore the possibility of whether an antioxidant can act via an ET process [33]. The observations that DHM could effectively reduce $\mathrm{Cu}^{2+}$ to $\mathrm{Cu}^{+}$at concentrations of 8-20 $\mathrm{g} / \mathrm{mL}$ (Figure 4B), further verified the possibility it acts via ET. Of course, the ET may also have a role in the repairing DNA radical by DHM [25]. 
However, the possibility that DHM participates in an ET process was less likely than that of myricitrin, as suggested by the $\mathrm{IC}_{50}$ ratios in Table 1 (0.5 vs 1.8 and 1.3 vs 3.0, for the $\mathrm{ABTS}^{+} \bullet$ and $\mathrm{Cu}^{2+}$-reducing assay, respectively). After ET, DHM would be transformed into a DHM• radical. The DHM• radical is actually a phenoxy• radical which needs a large conjugative system for delocalization and stabilization. However, as shown in Figure 1B, the 2,3-double bond saturated with two hydrogen atoms might block the formation of a larger conjugative system with $C \& A$ rings. Hence, the DHM• radical would be unstable, and this instability would partially prevent the occurrence of the ET pathway. Myricitrin, containing a 2,3-double bond (Figure S1), can form a larger conjugative system with $C \& A$ rings to delocalize and stabilize the phenoxy• radical. Therefore, myricitrin is more likely to undergo ET, and have stronger $\mathrm{ABTS}^{+} \bullet$ scavenging and $\mathrm{Cu}^{2+}$-reducing abilities regardless of the presence of a large sterically hindered glucoside.

In addition to the ET pathway, an atom transfer pathway has also been reported to play a role in the antioxidant action of phenolics [34]. Atom transfer can be further classified into several subtypes: hydrogen atom transfer (HAT), concerted proton-coupled electron transfer (CPCET), electron transfer followed by proton transfer (ET-PT), proton transfer followed by electron transfer (PT-ET), and sequential proton loss electron transfer (SPLET) among others [35]. As a stable free radical, DPPH• can be reduced by phytophenols to DPPH-H (Equation (3)) [36]. This is demonstrated to be an atom transfer [37], and thus, we analyzed the DPPH• scavenging ability of DHM:

$$
\mathrm{DPPH} \bullet+\text { phytophenol-OH } \rightarrow \text { DPPH-H + phytophenol-O• }
$$

As shown in Figure 7A, DHM scavenged DPPH• radical in a concentration dependent manner from 2 to $10 \mu \mathrm{g} / \mathrm{mL}$. This indicates that DHM acted through the atom transfer pathway to exert its antioxidant action. The $\mathrm{IC}_{50}$ value ratios in Table 1 suggested that DHM was more effective (4.7 vs 1.2) than myricitrin. Thus, relative to myricitrin, DHM might be more prone to act via the atom transfer pathway in the DPPH•-scavenging process. We presumed that the C-3 glucoside in myricitrin might sterically hinder the atom transfer. This presumption is further confirmed by our observation in the $\bullet \mathrm{O}_{2}{ }^{-}$scavenging assay (Figure 7B) where DHM possessed a stronger (4.7 vs 1.2$) \bullet \mathrm{O}_{2}^{-}$scavenging effect than myricitrin (Table 1). The atom transfer pathway has been proven to play a role in $\bullet \mathrm{O}_{2}{ }^{-}$ scavenging [38]. Our data are in accordance with previous findings that indicated that the glycosidation of the 3-OH will promote its stability during extraction [39].
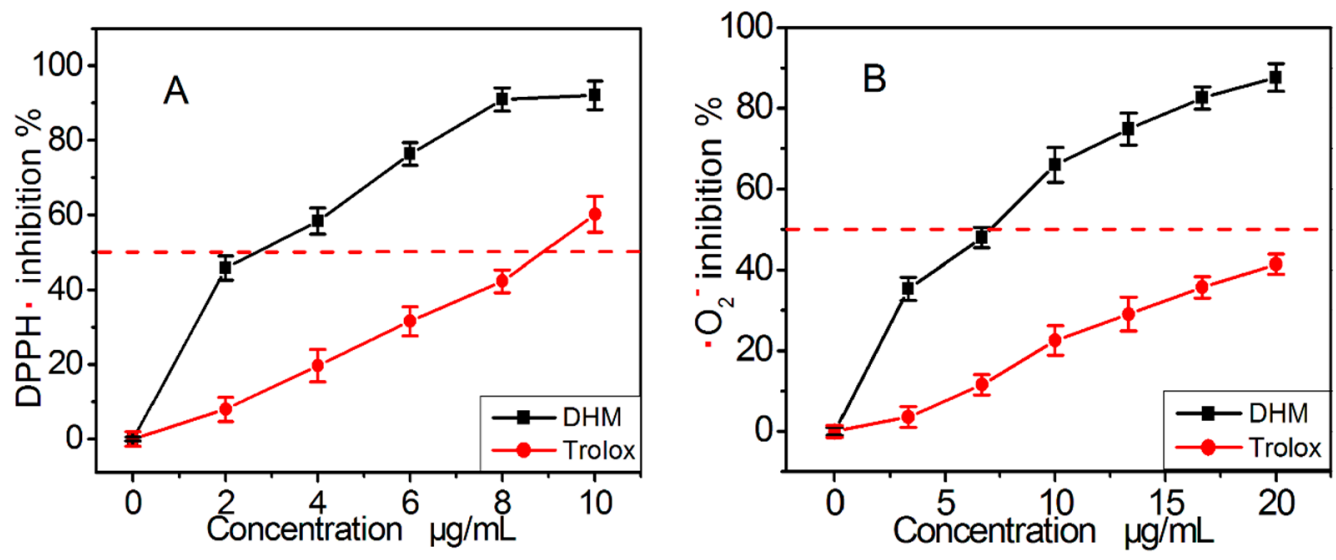

Figure 7. The dose response curves of dihydromyricetin (DHM) and the positive control Trolox in the DPPH• scavenging assay (A) and $\bullet \mathrm{O}_{2}{ }^{-}$scavenging assay (B). Each value is expressed as the mean \pm SD $(n=3)$. Trolox, [( \pm )-6-hydroxyl-2,5,7,8-tetramethlychroman-2-carboxylic acid].

Hydrogenation of the 2,3-double bond in a flavonoid diminishes its ability to participate in ET while glycosidation of the 3-OH can reduce its ability to participate in an atom transfer. Thus, 
the viewpoint that the 2,3-double bond does not play an important role in the improvement of a flavonoid's antioxidant ability is inappropriate [40]. Instead, in an ET-favored antioxidant process, the 2,3-double bond plays an important role while in an atom transfer-favored antioxidant process, the 2,3-double bond plays a minor role.

As mentioned above, metal chelation is one approach for phytophenols to scavenge ROS in cells. Therefore, we studied DHM using a $\mathrm{Fe}^{2+}$-chelating assay. As shown in Figure 8A, DHM chelated $\mathrm{Fe}^{2+}$ in a dose-dependent manner from 37.5 to $187.5 \mu \mathrm{g} / \mathrm{mL}$. Compared with sodium citrate (a very strong chelator), DHM has 0.8-times the relative chelating level (Table 1). This indicates that $\mathrm{DHM}$ is a reasonable $\mathrm{Fe}^{2+}$-chelator and $\mathrm{Fe}^{2+}$-chelation may be another mechanism for DHM to scavenge ROS. In our experiment, the DHM-Fe ${ }^{2+}$ complex with its bluish purple color (Figure S2) had an absorption maximum at $589 \mathrm{~nm}$, while DHM with its very light yellow color (Figure S3) had an absorption maximum at $332 \mathrm{~nm}$ (Figure 8B). The large bathochromic shift $\left(\lambda_{\max } 332 \rightarrow 589\right.$ $\mathrm{nm}$ ) obviously indicated an extension of aromatic conjugation. Based on our data and previous reports $[41,42]$, the $\mathrm{Fe}^{2+}$-chelating activity of $\mathrm{DHM}$ was proposed to arise from ortho- or adjacent hydroxyl groups and a carbonyl group, i.e., the $5,3^{\prime}, 4^{\prime}, 5^{\prime}-\mathrm{OH}$ groups and the 4-C=O group (Figure 9). These $s p^{2}$ carbons have a planar configuration and can readily form a stable five- or six-member ring through the chelation of $\mathrm{Fe}^{2+}$. However, the C-3 is $s p^{3}$ hybridized, making it an $R$-configuration (not a planar configuration) (Figure 1B). Therefore, the 3-OH group does not share a plan with the adjacent carbonyl group $(4-\mathrm{C}=\mathrm{O})$, making it difficult to form a stable ring-shaped $\mathrm{Fe}^{2+}$-complex with the $4-\mathrm{C}=\mathrm{O}$. Our interpretation is further supported by the previous finding that the 2,3-double bond was essential for stable copper chelation [43].
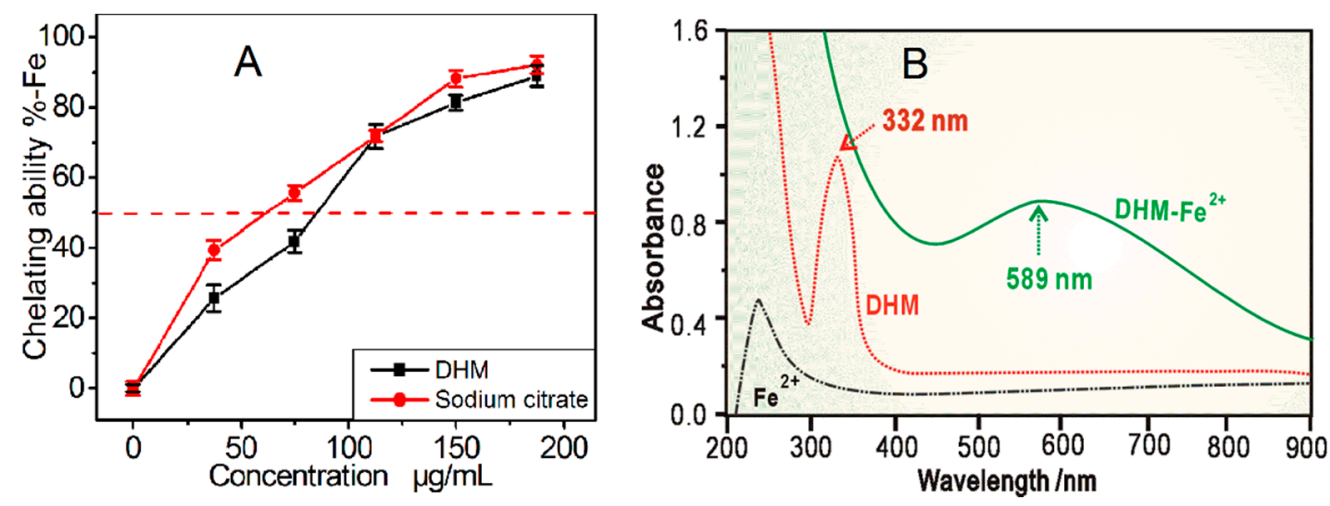

Figure 8. (A) The dose response curve of DHM in the $\mathrm{Fe}^{2+}$-chelating assay. Sodium citrate is used as the positive control. Each value in (A) is expressed as the mean $\pm \mathrm{SD}(n=3)$; (B) UV spectra of dihydromyricetin (DHM) and the DHM-Fe ${ }^{2+}$ complex.

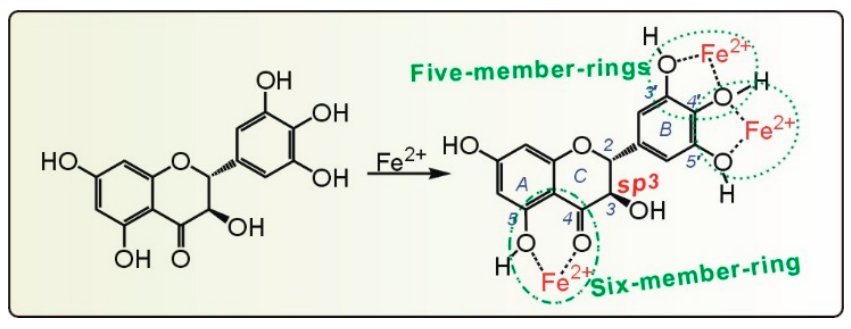

Figure 9. The proposed chelation of $\mathrm{Fe}^{2+}$ by dihydromyricetin (DHM).

Additionally, the 3-OH group is unlikely to undergo hemolytic rupture to produce a hydrogen radical $(\bullet \mathrm{H})$ and alkoxyl radical $(\bullet \mathrm{OR})$, because it is an alcoholic $-\mathrm{OH}$ group not a phenolic $-\mathrm{OH}$. Thus, the view that the $3-\mathrm{OH}$ group along with the $5,3^{\prime}, 4^{\prime}, 5^{\prime}-\mathrm{OH}$ and $4-\mathrm{C}=\mathrm{O}$ groups plays an important role in the antioxidant of DHM is not reasonable [8]. 


\section{Materials and Methods}

\subsection{Chemicals and Animals}

Dihydromyricetin (DHM, CAS 27200-12-0, 98\%) was purchased from Chengdu Biopurify Phytochemicals Ltd. (Chengdu, China). Dulbecco's modified Eagle's medium (DMEM) and fetal bovine serum (FBS) were purchased from Gibco (Grand Island, NY, USA). CD44 was from Wuhan Boster Co., Ltd. (Wuhan, China). Annexin V/propidium iodide (PI) assay kit was purchased from Invitrogen (Carlsbad, CA, USA). DPPH• (1,1-diphenyl-2-picrylhydrazyl radical), neocuproine (2,9-dimethyl-1,10-phenanthroline hemihydrate), Trolox [( \pm )-6-hydroxyl-2,5,7,8-tetramethly chroman-2-carboxylic acid], ferrozine [3-(2-pyridyl)-5,6-bis(4-phenylsulfonicacid)-1,2,4-triazine], 3-(4,5-dimethylthiazol-2-yl)-2,5-diphenyl (MTT), and pyrogallol were purchased from Sigma Co. (Sigma-Aldrich Shanghai Trading Co., Shanghai, China); 2,2'-Azino-bis(3-ethylbenzothiazoline -6-sulfonic acid diammonium salt) (ABTS) was obtained from Amresco Inc. (Solon, OH, USA); DNA sodium salt (fish sperm) was purchased from Aladdin Chemistry Co. (Shanghai, China); hydrogen peroxide $\left(\mathrm{H}_{2} \mathrm{O}_{2}, \mathrm{AR}\right)$, ferrous chloride $\left(\mathrm{FeCl}_{2} \cdot 4 \mathrm{H}_{2} \mathrm{O}\right.$, $\left.\mathrm{AR}\right)$, and dimethyl sulfoxide (DMSO, AR) were from Guangzhou Chemical Reagent Factory (Guangzhou, China). Four-week-old Sprague-Dawley (SD) rats were obtained from the animal center of Guangzhou University of Chinese Medicine. Procurement, maintenance and treatments to animals were performed under the supervision of the Institutional Animal Ethics Committee in Guangzhou University of Chinese Medicine.

\subsection{Protective Effect Against $\bullet$ OH-Induced Damage to Mscs (MTT Assay)}

MSC culture and the MTT assay were carried out according to our previous report [44]. In brief, bone marrow was obtained from the femur and tibia of rat. The marrow samples were diluted with DMEM (LG: low glucose) containing 10\% FBS. MSCs were prepared by gradient centrifugation at $900 \times \mathrm{g}$ for $30 \mathrm{~min}$ on Percoll of a density of $1.073 \mathrm{~g} / \mathrm{mL}$. The cells were washed, counted, and plated at $1 \times 10^{6} / \mathrm{cm}^{2}$ on Petri dishes in DMEM-LG supplemented with $10 \%$ FBS. The medium was replaced and the unattached cells were removed every 3 days. MSCs formed as confluent layers were detached by treatment with $0.25 \%$ trypsin and passaged into culture flasks at $1 \times 10^{4} / \mathrm{cm}^{2}$. MSCs at passage 3 were evaluated for cultured cell homogeneity using detection of CD44 by flow cytometry and used for the MTT assay. For the assay, the cultured MSCs were divided into control, model, and sample DHM groups. In the control group, MSCs were incubated for $24 \mathrm{~h}$ in DMEM. In the model and sample groups, MSCs were treated with $\mathrm{FeCl}_{2}(100 \mu \mathrm{M})$ followed by $\mathrm{H}_{2} \mathrm{O}_{2}(50 \mu \mathrm{M})$. After incubation for $25 \mathrm{~min}$, the mixture of $\mathrm{FeCl}_{2}$ plus $\mathrm{H}_{2} \mathrm{O}_{2}$ was removed. MSCs in the model group were incubated for $24 \mathrm{~h}$ in DMEM, while MSCs in the sample group were incubated for $24 \mathrm{~h}$ in DMEM with various DHM concentrations. After incubation, $20 \mu \mathrm{L}$ MTT $(5 \mathrm{mg} / \mathrm{mL}$ in PBS) was added and the culture was incubated for a further $3 \mathrm{~h}$. The culture medium was discarded and replaced with $150 \mu \mathrm{L}$ DMSO. Absorbance at $490 \mathrm{~nm}$ was measured using a Bio-Kinetics reader (PE-1420; Bio-Kinetics Corporation, Sioux Center, IA, USA). The culture with the serum medium was used for the control group and each sample test was repeated in five independent wells. The cell viability (\% control) was calculated based on the $\mathrm{A}_{490 \mathrm{~nm}}$.

\subsection{Flow Cytometry Analysis for Annexin V and PI}

In the control group, MSCs were incubated in DMEM. In the model and sample groups, MSCs were treated with $\mathrm{FeCl}_{2}(100 \mu \mathrm{M})$ followed by $\mathrm{H}_{2} \mathrm{O}_{2}(50 \mu \mathrm{M})$. After incubation for $25 \mathrm{~min}$, the mixture of $\mathrm{FeCl}_{2}$ and $\mathrm{H}_{2} \mathrm{O}_{2}$ was removed. MSCs in the model group were incubated for $24 \mathrm{~h}$ in DMEM, while MSCs in the sample group were incubated for $24 \mathrm{~h}$ in DMEM with various DHM concentrations. After culture, cells were harvested by trypsin $(0.05 \%)$ digestion in phosphate-buffered saline (PBS). The cells were washed and re-suspended in PBS, fixed in 70\% ethanol and washed with PBS. In the next step, they were labeled with Annexin V and $50 \mu \mathrm{g} / \mathrm{mL}$ PI and ribonuclease (RNase) $(10 \mu \mathrm{g} / \mathrm{mL}$ ) and then incubated at $37^{\circ} \mathrm{C}$ for $45 \mathrm{~min}$. Fluorescence was measured using flow cytometry (EPICS XL, 
Coulter, Pasadena, CA, USA) with standard software. Experiments were performed with 2 different batches of cells and each batch was tested in duplicate.

\subsection{Protective Effect against Hydroxyl-Induced DNA Damage (DNA Protection Assay)}

The protective effect against $\bullet \mathrm{OH}$-induced DNA damage was estimated using the method developed by our laboratory [45]. Briefly, methanol sample solutions $(0.1 \mathrm{mg} / \mathrm{mL}, 20-120 \mu \mathrm{L})$ were separately aliquoted into mini tubes. After completely evaporating the methanol solvent in each tube at $60{ }^{\circ} \mathrm{C}$, the sample residue was treated with $300 \mu \mathrm{L}$ phosphate buffer $(0.2 \mathrm{M}, \mathrm{pH} 7.4)$, followed by $100 \mu \mathrm{L}$ DNA sodium $(10 \mathrm{mg} / \mathrm{mL}), 75 \mu \mathrm{L} \mathrm{H}_{2} \mathrm{O}_{2}(33.6 \mathrm{mM}), 50 \mu \mathrm{L} \mathrm{FeCl}_{3}(3.2 \mathrm{mM}), 100 \mu \mathrm{L} \mathrm{Na}{ }_{2}$ EDTA $(0.5 \mathrm{mM})$, and $75 \mu \mathrm{L}$ ascorbic acid $(12 \mathrm{mM})$. The total volume of the reaction mixture was brought up to $800 \mu \mathrm{L}$ with buffer. After incubation at $55^{\circ} \mathrm{C}$ for $20 \mathrm{~min}, 250 \mu \mathrm{L}$ of trichloroacetic acid $(10 \%, w / w)$ was added to the tube. After heating the mixture at $105^{\circ} \mathrm{C}$ for $15 \mathrm{~min}$ with $150 \mu \mathrm{L}$ 2-thiobarbituric acid (TBA, $5 \%$ in $1.25 \% \mathrm{NaOH}$ aqueous solution), the absorbance was measured at $530 \mathrm{~nm}$ (Unico 2100, Shanghai, China) against the buffer (as the blank). The protective percentage is expressed as follows:

$$
\text { Protective effect } \%=\frac{\mathrm{A}_{0}-\mathrm{A}}{\mathrm{A}_{0}} \times 100 \%
$$

where $\mathrm{A}_{0}$ indicates the absorbance of the blank and $\mathrm{A}$ indicates the absorbance of the sample.

\subsection{Pyrogallol Autoxidation Assay for $\bullet \mathrm{O}^{2-}$ Scavenging}

The pyrogallol autoxidation assay is used to evaluate the superoxide anion $\left(\bullet \mathrm{O}_{2}{ }^{-}\right)$scavenging activity of antioxidants and was previously established by our laboratory [46]. Briefly, 0-600 $\mu \mathrm{L}$ of sample solution $(0.1 \mathrm{mg} / \mathrm{mL})$ was prepared in Tris- $\mathrm{HCl}$ buffer $\left(0.05 \mathrm{M}, \mathrm{pH}\right.$ 7.4) containing $\mathrm{Na}_{2} \mathrm{EDTA}$ $(1 \mathrm{mM})$ in a total volume of $2950 \mu \mathrm{L}$. Then about $50 \mu \mathrm{L}$ pyrogallol solution $(60 \mathrm{mM}$, in $1 \mathrm{mM} \mathrm{HCl})$ was added to the $2950 \mu \mathrm{L}$ mixture. After vigorous mixing, the absorbance was read at $325 \mathrm{~nm}$ every $30 \mathrm{~s}$ for $5 \mathrm{~min}$. The $\bullet \mathrm{O}_{2}{ }^{-}$scavenging ability was calculated as:

$$
\text { Inhibition } \%=\frac{\Delta \mathrm{A}_{325 \mathrm{~nm}, \text { control }}-\Delta \mathrm{A}_{325, \text { sample }}}{\Delta \mathrm{A}_{325, \text { control }}} \times 100 \%
$$

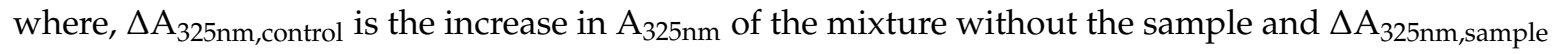
is that with the sample.

\section{6. $\mathrm{Cu}^{2+}$-Reducing Power Assay}

The $\mathrm{Cu}^{2+}$-reducing power assay was carried out according to a previously published method [47]. To $125 \mu \mathrm{L}$ of $\mathrm{CuSO}_{4}$ aqueous solution $(10 \mathrm{mM}), 125 \mu \mathrm{L}$ neocuproine solution $\left(7.5 \mathrm{mM}\right.$ in $\left.\mathrm{CH}_{3} \mathrm{OH}\right)$ and sample solutions $(0.1 \mathrm{mg} / \mathrm{mL}, 0-200 \mu \mathrm{L})$ at appropriate concentrations were added. Then, the total volume was adjusted to $1000 \mu \mathrm{L}$ with the buffer and mixed vigorously. Absorbance against a buffer blank was measured at $450 \mathrm{~nm}$ after $30 \mathrm{~min}$. The relative $\mathrm{Cu}^{2+}$-reducing power was calculated using the formula:

$$
\text { Relative reducing power } \%=\frac{A-A_{\min }}{A_{\max }-A_{\min }} \times 100 \%
$$

where, $A_{\max }$ is the maximum absorbance and $A_{\min }$ is the minimum absorbance in the test. $A$ is the absorbance of sample.

\subsection{DPPH•Radical-Scavenging Assay}

The scavenging activity on DPPH• free radicals was assessed according to the method reported by Li [48]. Briefly, $50 \mu \mathrm{L}$ of the methanolic sample solution (at least 5 different concentrations were prepared, 30-150 $\mu \mathrm{L}$ ) was mixed with $100 \mu \mathrm{L} \mathrm{DPPH \bullet} \mathrm{solution} \mathrm{(100} \mu \mathrm{M}$ in methanol, prepared daily). The mixture was shaken vigorously and left to stand for $30 \mathrm{~min}$ in the dark, and the absorbance 
was then measured at $519 \mathrm{~nm}$ against a blank. The DPPH•-scavenging activity of each solution was calculated as the percent inhibition according to the following equation:

$$
\text { Protective effect } \%=\frac{A_{0}-A}{A_{0}} \times 100 \%
$$

where $\mathrm{A}_{0}$ and $\mathrm{A}$ are the absorbance of the system in the absence and presence of sample, respectively.

\subsection{ABTS $^{+}$Radical-Scavenging Assay}

The $\mathrm{ABTS}^{+} \bullet$ scavenging activity was evaluated according to a previously published method [49]. The ABTS ${ }^{+}$was produced by mixing $200 \mu \mathrm{L}$ ABTS diammonium salt $(7.4 \mathrm{mM})$ with $200 \mu \mathrm{L} \mathrm{K}{ }_{2} \mathrm{~S}_{2} \mathrm{O}_{8}$ $(2.6 \mathrm{mM})$. After incubation in the dark for $12 \mathrm{~h}$, the mixture was diluted with methanol (about 1:50) so that its absorbance at $734 \mathrm{~nm}$ was $0.70 \pm 0.02$. Then, the diluted ABTS $\bullet$ solution $(800 \mu \mathrm{L})$ was added to $200 \mu \mathrm{L}$ of an ethanolic sample solution at various concentrations, and thoroughly mixed. After the reaction mixture stood for $6 \mathrm{~min}$, the absorbance at $734 \mathrm{~nm}$ was read on a spectrophotometer. The percentage inhibition was calculated by the same formula used for the $\mathrm{DPPH} \bullet$ radical-scavenging assay.

\subsection{Colorimetry Determination and UV Spectra Determination of $\mathrm{Fe}^{2+}$-Chelation}

The $\mathrm{Fe}^{2+}$ chelating activity of DHM was estimated by a colorimetric method [50]. Briefly, 0-150 $\mu \mathrm{L}$ of sample solution $\left(0.1 \mathrm{mg} / \mathrm{mL}\right.$ in methanol) was added to $100 \mu \mathrm{L} \mathrm{FeCl}_{2}$ aqueous solution $(250 \mu \mathrm{M})$. The reaction was initiated by the addition of $150 \mu \mathrm{L}$ ferrozine aqueous solution $(1 \mathrm{mM})$ and the total volume of the system was adjusted to $1000 \mu \mathrm{L}$ with methanol. Then, the mixture was shaken vigorously and incubated at room temperature for $10 \mathrm{~min}$. The absorbance of the solution was recorded at $562 \mathrm{~nm}$ (Unico 2100). The percentage of the chelating effect was calculated by the formula described in the DNA protection assay section. UV spectra analysis was also completed on the $\mathrm{DHM}-\mathrm{Fe}^{2+}$ complex. A total of $200 \mu \mathrm{L}$ methanol DHM solution $(1 \mathrm{mg} / \mathrm{mL})$ was added to $300 \mu \mathrm{L} \mathrm{FeCl}_{2} \bullet 4 \mathrm{H}_{2} \mathrm{O}$ aqueous solution. Then the mixture was ultrasonicated then centrifuged at $6500 \times g$ for $10 \mathrm{~min}$. The supernatant spectrum was obtained using a UV/Vis spectrophotometer (Jinhua 754 PC, Shanghai, China).

\subsection{Statistical Analysis}

Data are given as the mean $\pm \mathrm{SD}$ of three measurements. The $\mathrm{IC}_{50}$ values were calculated by linear regression analysis using Origin 6.0 professional software (Northampton, MA, USA). Determination of significant differences between the mean $\mathrm{IC}_{50}$ values of the sample and the positive control was performed using one-way ANOVA. The analysis was performed using SPSS software 13.0 (SPSS Inc., Chicago, IL, USA) for Windows. A value of $p<0.05$ was considered to be statistically significant.

\section{Conclusions}

DHM can effectively protect MSCs against $\bullet \mathrm{OH}$-induced damage. This protective effect suggests a potential role for DHM in MSC transplantation therapy, and may be attributed to its antioxidant ability. The possible antioxidant mechanisms are thought to include direct radical-scavenging and $\mathrm{Fe}^{2+}$-chelation. Direct radical-scavenging uses an ET pathway. The hydrogenation of the 2,3-double bond is hypothesized to reduce the ET by blocking the formation of a larger $\pi-\pi$ conjugative system. The glycosidation of the 3-OH in myricitrin is assumed to sterically hinder atom transfer in $\bullet \mathrm{O}_{2}{ }^{-}$and DPPH• radical scavenging. Therefore, hydrogenation of the flavonoid 2,3-double bond diminishes its ability to scavenge radicals via ET, while glycosidation of the 3-OH can reduce its ability to participate in atom transfer. In DHM, the $\mathrm{Fe}^{2+}$-chelating effect can actually be attributed to the $5,3^{\prime}, 4^{\prime}, 5^{\prime}-\mathrm{OH}$ and $4-\mathrm{C}=\mathrm{O}$ groups, and the $3-\mathrm{OH}$ group itself can neither scavenge radicals nor chelate metal.

Supplementary Materials: Supplementary materials can be accessed at: http://www.mdpi.com/1420-3049/21/ 5/604/s1. 
Acknowledgments: This work was supported by the National Nature Science Foundation of China (81273896, 81573558, 81303116), and High Level Universities Construction Special Foundation of Guangdong in 2015 (2050205).

Author Contributions: Xican Li and Dongfeng Chen conceived and designed the experiments; Jinging Liu, Jian Lin and Tingting Wang performed the experiments; Jieyuan Huang and Yongqiang Lin analyzed the data; Xican Li wrote the paper. All authors read and approved the final manuscript.

Conflicts of Interest: The authors declare no conflict of interest.

\section{Abbreviations}

The following abbreviations are used in this manuscript:

$\begin{array}{ll}\text { ABTS } & \text { 2,2'-azino-bis (3-ethylbenzothiazoline-6-sulfonic acid } \\ \text { BHA } & \text { butylated hydroxyanisole } \\ \text { bmMSCs } & \text { bone marrow derived mesenchymal stem cells } \\ \text { DHM } & \text { Dhydromyricetin } \\ \text { DMEM } & \text { Dulbecco's modified Eagle's medium } \\ \text { DPPH } & \text { 1,1-diphenyl-2-picrylhydrazyl radical } \\ \text { ET } & \text { electron transfer } \\ \text { FBS } & \text { fetal bovine serum } \\ \text { Ferrozine } & \text { 3-(2-pyridyl)-5, 6-bis (4-phenylsulfonicacid)-1,2,4-triazine } \\ \text { MSCs } & \text { mesenchymal stem cells } \\ \text { MTT } & {[3-(4,5-\text { dimethylthiazol-2-yl)-2,5-diphenyl] }} \\ \text { ROS } & \text { reactive oxygen species } \\ \text { SD } & \text { standard deviation } \\ \text { TBA } & \text { 2-thiobarbituric acid } \\ \text { TCM } & \text { Tradition Chinese Medicine } \\ \text { Tris } & \text { Tri-hydroxymethyl amino methane } \\ \text { Trolox } & ( \pm \text {-6-hydroxyl-2,5,7,8-tetramethlychroman-2-carboxylic acid }\end{array}$

\section{References}

1. Kim, E.Y.; Lee, K.B.; Kim, M.K. The potential of mesenchymal stem cells derived from amniotic membrane and amniotic fluid for neuronal regenerative therapy. BMB Rep. 2014, 47, 135-140. [CrossRef] [PubMed]

2. Chen, M.; Li, X.; Zhang, X.; He, X.; Lai, L.; Liu, Y.; Zhu, G.; Li, W.; Li, H.; Fang, Q.; et al. The inhibitory effect of mesenchymal stem cell on blood-brain barrier disruption following intracerebral hemorrhage in rats: Contribution of TSG-6. J. Neuroinflamm. 2015, 12. [CrossRef] [PubMed]

3. Bang, O.; Lee, J.S.; Lee, P.H.; Lee, G. Autologous mesenchymal stem cell transplantation in stroke patients. Ann. Neurol. 2005, 57, 874-882. [CrossRef] [PubMed]

4. Calió, M.L.; Marinho, D.S.; Ko, G.M.; Ribeiro, R.R.; Carbonel, A.F.; Oyama, L.M.; Ormanji, M.; Guirao, T.P.; Calió, P.L.; Reis, L.A.; et al. Transplantation of bone marrow mesenchymal stem cells decreases oxidative stress, apoptosis, and hippocampal damage in brain of a spontaneous stroke model. Free Radic. Biol. Med. 2014, 70, 141-154. [CrossRef] [PubMed]

5. Ayatollahi, M.; Hesami, Z.; Jamshidzadeh, A.; Gramizadeh, B. Antioxidant Effects of Bone Marrow Mesenchymal Stem Cell against Carbon Tetrachloride-Induced Oxidative Damage in Rat Livers. Int. J. Organ. Transplant. Med. 2014, 5, 166-173. [PubMed]

6. Narita, T.; Suzuki, K. Bone marrow-derived mesenchymal stem cells for the treatment of heart failure. Heart Fail. Rev. 2015, 20, 53-68. [CrossRef] [PubMed]

7. Zeng, W.; Xiao, J.; Zheng, G.; Xing, F.; Tipoe, G.L.; Wang, X.; He, C.; Chen, Z.Y.; Liu, Y. Antioxidant treatment enhances human mesenchymal stem cell anti-stress ability and therapeutic efficacy in an acute liver failure model. Sci. Rep. 2015, 5. [CrossRef] [PubMed] 
8. Zhang, Y.S.; Ning, Z.X.; Yang, S.Z.; Wu, H. Antioxidation properties and mechanism of action of dihydromyricetin from Ampelopsis grossedentata. Yao Xue Xue Bao 2003, 38, 241-244. [PubMed]

9. Hou, X.; Tong, Q.; Wang, W.; Xiong, W.; Shi, C.; Fang, J. Dihydromyricetin protects endothelial cells from hydrogen peroxide-induced oxidative stress damage by regulating mitochondrial pathways. Life Sci. 2015, 130, 38-46. [CrossRef] [PubMed]

10. Ye, L.; Wang, H.; Duncan, S.E.; Eigel, W.N.; O'Keefe, S.F. Antioxidant activities of Vine Tea (Ampelopsis grossedentata) extract and its major component dihydromyricetin in soybean oil and cooked ground beef. Food Chem. 2015, 172, 416-422. [CrossRef] [PubMed]

11. Tan, L.T. Research Advance in Chemical Components and Pharmacological Actions of Rattan Tea. SH. J. TCM Jun. 2008, 42, 94-96.

12. Chen, Y.Q.; Jiang, N.D.; Cheng, Q.; Huang, H.B.; Meng, Y.M.; Wu, C. Study on the Hypolipidemic Effect of Flavones and Dihydromyricetin From Tengcha. J. Tea Sci. 2007, 27, 221-225.

13. Fang, Y.Z.; Zheng, R.L. Theory and Application of Free Radical Biology, 1st ed.; Science Press: Beijing, China, 2002; pp. 759-761.

14. Zhu, H.; Luo, P.; Fu, Y. Dihydromyricetin prevents cardiotoxicity and enhances anticancer activity induced by Adriamycin. Oncotarget 2015, 6, 3254-3267. [CrossRef] [PubMed]

15. Shen, Y.; Lindemeyer, A.K.; Gonzalez, C.; Shao, X.M.; Spigelman, I. Dihydromyricetin as a novel anti-alcohol intoxication medication. J. Neurosci. 2012, 32, 390-401.

16. Li, C.P.; Cao, S.W.; Yu, Y.Y. Advanced Study on Dihydromyricetin. Chem. Reag. 2010, 32, 608-612.

17. Li, W.; Wu, H.; Liu, B.G.; Hou, X.D.; Wan, D.J. Highly efficient and regioselective synthesis of dihydromyricetin esters by immobilized lipase. J. Biotechnol. 2015, 199, 31-37. [CrossRef] [PubMed]

18. Zhang, Y.S.; Zhang, Q.Y.; Li, L.Y.; Wang, B.; Zhao, Y.Y. Simultaneous determination and pharmacokinetic studies of dihydromyricetin and myricetin in rat plasma by HPLC-DAD after oral administration of Ampelopsis grossedentata decoction. J. Chromatogr. B Anal. Technol. Biomed. Life Sci. 2007, 860, 4-9. [CrossRef] [PubMed]

19. Nicolay, N.H.; Lopez, P.R.; Saffrich, R.; Huber, P.E. Radio-resistant mesenchymal stem cells: Mechanisms of resistance and potential implications for the clinic. Oncotarget 2015, 6, 19366-19380. [CrossRef] [PubMed]

20. Zhang, Y.; Zhai, W.; Zhao, M.; Li, D.; Chai, X.; Cao, X.; Meng, J.; Chen, J. Effects of Iron Overloadon the Bone Marrow Microenvironment in Mice. PLoS ONE 2015, 10, e0120219.

21. Yang, S.R.; Park, J.R.; Kang, K.S. Reactive Oxygen Species in Mesenchymal Stem Cell Aging: Implication to Lung Diseases. Oxid. Med. Cell Longev. 2015, 10, 1155-1166. [CrossRef] [PubMed]

22. Sung, K.W.; Lim, D.H.; Yi, E.S.; Choi, Y.B.; Lee, J.W.; Yoo, K.H.; Koo, H.H.; Kim, J.H.; Suh, Y.L.; Joung, Y.S.; et al. Tandem High-Dose Chemotherapy and Autologous Stem Cell Transplantation for Atypical Teratoid/Rhabdoid Tumor. Cancer Res. Treat. 2016. [CrossRef] [PubMed]

23. Liao, S.F.; Wang, H.T.; Yan, F.X.; Zheng, Y.X.; Zeng, Z.W.; Zheng, W.H. Protective effect and mechanisms of dihydromyricetin on PC12 cells induced by oxidative injury. Zhong Yao Cai 2014, 37, 1014-1020. [PubMed]

24. Li, W.; Li, Q.; Guo, F.Q.; Gu, R.Q. DNA Damage Induced by X-irradiation and Reactive Oxygen Species and the Protection Against by Sinapine. Acta Phytophysiol. Sin. 1997, 23, 319-323.

25. Zheng, R.L.; Shi, Y.M.; Jia, Z.J.; Zhao, C.Y.; Zhang, Q.; Tan, X.R. Fast repair of DNA radicals. Chem. Soc. Rev. 2010, 39, 2827-2834. [CrossRef] [PubMed]

26. Li, X.C.; Mai, W.; Chen, D.F. Chemical Study on Protective Effect Against Hydroxyl-induced DNA Damage and Antioxidant Mechanism of Myricitrin. J. Chin. Chem. Soc. 2014, 61, 383-390. [CrossRef]

27. Yang, X.M.; Wang, X.H.; Chen, L.F. Effects of dihydromyricetin on tumor necrosis factor and NF-kappaB p65 of RAU rats. Zhongguo Zhong Yao Za Zhi 2012, 37, 2612-2617. [PubMed]

28. Fang, Y.Z.; Zheng, R.L. Theory and Application of Free Radical Biology, 1st ed.; Science Press: Beijing, China, 2002; pp. 98-99.

29. Villata, L.S.; Berkovic, A.M.; Gonzalez, M.C.; Mártire, D.O. One-electron oxidation of antioxidants: A kinetic-thermodynamic correlation. Redox Rep. 2013, 18, 205-214. [CrossRef] [PubMed]

30. Changha, L.; Jeyong, Y. UV direct photolysis of 2,2'-azino-bis(3-ethylbenzothiazoline-6-sulfonate) (ABTS) in aqueous solution: Kinetics and mechanism. J. Photochem. Photobiol. A Chem. 2008, 197, 232-238.

31. Aliaga, C.; Lissi, E.A. Reactions of the radical cation derived from 2,2'-azinobis(3-ethylbenzothiazoline -6-sulfonic acid) $\left(\mathrm{ABTS}^{+}\right)$with amino acids. Kinetics and mechanism. Inter. J. Chem. Kin. 1998, 30, 565-570. [CrossRef] 
32. Fang, Y.Z.; Zheng, R.L. Theory and Application of Free Radical Biology, 1st ed.; Science Press: Beijing, China, 2002; pp. 102-103.

33. Sema, D.C.; Kevser, S.B.; Esma, T. Modified cupric reducing antioxidant capacity (CUPRAC) assay for measuring the antioxidant capacities of thiol-containing proteins in admixture with polyphenols. Talanta 2009, 79, 344-351.

34. Wright, J.S.; Johnson, E.R.; DiLabio, G.A. Predicting the Activity of Phenolic Antioxidants: Theoretical Method, Analysis of Substituent Effects, and Application to Major Families of Antioxidants. J. Am. Chem. Soc. 2001, 123, 1173-1183. [CrossRef] [PubMed]

35. Holtomo, O.; Nsangou, M.; Fifen, J.J.; Motapon, O. DFT study of the effect of solvent on the $\mathrm{H}$ atom transfer involved in the scavenging of the free radicals $\bullet \mathrm{HO}_{2}$ and $\bullet \mathrm{O}_{2}{ }^{-}$by caffeic acid phenethyl ester and some of its derivatives. J. Mol. Model. 2014, 20, 2509-2522. [CrossRef] [PubMed]

36. Honda, N.K.; Lopes, T.I.; Costa, R.C.; Coelho, R.G. Radical-scavenging Potential of Phenolic Compounds from Brazilian Lichens. Orbital Electron. J. Chem. 2015, 7, 99-107. [CrossRef]

37. Boudiera, A.; Tournebizea, J.; Bartoszb, G.; Hanic, S.E.; Bengueddourc, R. High-performance liquid chromatographic method to evaluate the hydrogen atom transfer during reaction between 1,1-diphenyl-2-picryl-hydrazyl radical and antioxidants. Anal. Chim. Acta 2012, 711, 97-106. [CrossRef] [PubMed]

38. Jovanovic, S.V.; Hara, Y.; Steenken, S.; Simic, M.G. Antioxidant Potential of Gallocatechins. A Pulse Radiolysis and Laser Photolysis Study. J. Am. Chem. Soc. 1995, 117, 9881-9888. [CrossRef]

39. Biesaga, M. Stability of bioactive polyphenols from honey during different extraction methods. Food Chem. 2013, 136, 46-54. [CrossRef] [PubMed]

40. Xin, M.; Ma, Y.; Lin, W.; Kai, X.; Chen, M. Study on the structure-activity of dihydromyricetin and its new production. J. Therm. Anal. Calorim. 2014, 116, 241-248. [CrossRef]

41. Torreggiani, A.; Tamba, M.; Trinchero, A.; Bonora, S. Copper(II)-quercetin complexes in aqueous solutions: Spectroscopic and kinetic properties. J. Mol. Struct. 2005, 744, 759-766. [CrossRef]

42. Schinella, G.; Mosca, S.; Pasamar, M.A.; Muguerza, B.; Ramón, D.; Ríos, J.L. Antioxidant properties of polyphenol-rich cocoa products industrially processed. Food Res. Int. 2010, 43, 1614-1623. [CrossRef]

43. Ǩ́íha, M.; Karlíčková, J.; Filipský, T.; Rocha, L.; Saso, L.; Jahodář, L.; Mladěnka, P. In vitro evaluation of copper-chelating properties of flavonoids. RSC Adv. 2014, 14, 405-422. [CrossRef]

44. Li, X.C.; Gao, Y.; Li, F.; Liang, A.; Xu, Z.; Bai, Y.; Mai, W.; Chen, D.F. Maclurin protects against hydroxyl radical-induced damages to mesenchymal stem cells: Antioxidant evaluation and mechanistic insight. Chem. Biol. Interact. 2014, 219, 221-228. [CrossRef] [PubMed]

45. Li, X.C.; Lin, J.; Gao, Y. Antioxidant activity and mechanism of Rhizoma Cimicifugae. Chem. Cent. J. 2012, 6, 140-150. [CrossRef] [PubMed]

46. Li, X.C. Improved pyrogallol autoxidation method: A reliable and cheap superoxide-scavenging assay suitable for all antioxidants. J. Agric. Food Chem. 2012, 60, 6418-6424. [CrossRef] [PubMed]

47. Li, X.C.; Han, W.; Mai, W. Antioxidant activity and mechanism of Tetrahydroamentoflavone in vitro. Nat. Prod. Commun. 2013, 8, 787-789.

48. Lin, J.; Li, X.C.; Han, L. Folium Sennae protects against hydroxyl radical-induced DNA damage via antioxidant mechanism: An in vitro study. Bot. Stud. 2014, 55, 16-24. [CrossRef]

49. Lin, J.; Li, X.C.; Chen, L. Protective Effect Against Hydroxyl Radical-induced DNA Damage and Antioxidant Mechanism of [6]-gingerol: A Chemical Study. Bull. Korean Chem. Soc. 2014, 35, 1633-1638. [CrossRef]

50. Gülçn, İ. Antioxidant properties of resveratrol: A structure-activity insight. Innov. Food Sci. Emerg. 2010, 11, 210-218.

Sample Availability: Sample of the compound dihydromyricetin is available from the authors.

(C) 2016 by the authors; licensee MDPI, Basel, Switzerland. This article is an open access article distributed under the terms and conditions of the Creative Commons Attribution (CC-BY) license (http://creativecommons.org/licenses/by/4.0/). 